\section{Encontro marcado entre demografia $e$ religião}

\author{
Paula Miranda-Ribeiro*
}

\begin{abstract}
ELLISON, Christopher G.; HUMMER, Robert A. (Eds.). Religion, families and health: populationbased research in the United States. New Brunswick: Rutgers, 2010. $468 \mathrm{p}$.
\end{abstract}

Tanto o romance de Fernando Sabino, de 1956, quanto o volume editado por Christopher G. Ellison e Robert A. Hummer, publicado em abril de 2010, tratam de um encontro marcado. Enquanto no livro de Sabino, Encontro marcado, amigos marcam um encontro para 15 anos depois, a coletânea Religion, families and health: population-based research in the United States mostra que o encontro da demografia com a religião, nos Estados Unidos, já estava marcado há muito mais tempo.

Com o objetivo de reunir diferentes análises do papel multifacetado da religião sobre importantes aspectos da vida familiar e da saúde nos Estados Unidos, o livro é organizado por dois grandes especialistas. Atualmente professor na University of Texas at San Antonio e autor de cerca de 150 artigos publicados em periódicos, mais da metade deles como primeiro autor, Ellison é referência obrigatória para quem estuda religião, enquanto Hummer, professor da University of Texas at Austin e agraciado com o Clifford C. Clogg Award da Population Association of America em 2010 - que premia, pela relevância da sua produção acadêmica, demógrafos que possuem alguma experiência, mas ainda não atingiram o status de profissional sênior (mid-career)
- tem como principal tema de pesquisa a mortalidade adulta.

Dividido em três partes e 21 capítulos, o livro de Elisson e Hummer reúne artigos escritos por sociólogos da religião e demógrafos sociais, alguns famosos e outros iniciantes, mas todos interessados nas relações entre religião, família e saúde nos Estados Unidos. A introdução, bastante detalhada, instigante e entusiasmada, faz um belo apanhado do que está por vir.

A primeira parte do livro, composta por dez capítulos, trata da relação entre religião e família. São abordados temas como fecundidade (Pearce), criação de filhos (Alvin e Felson), comportamento sexual dos adolescentes (Regnerus), laços entre gerações (King), valores familiares entre protestantes conservadores (Bartkowski e Xu) e católicos (Burdette e Sulivan), casamentos inter-religiões e conversão (Waite e Lewin), acumulação de bens entre jovens adultos (Keister), educação e salários (Lehrer) e emprego feminino entre muçulmanas e árabes cristãs americanas (Read).

A segunda parte, com oito capítulos, enfoca a associação entre religião e saúde. Os artigos discutem assuntos tais como depressão entre idosos (Krause), saúde física de adultos (Musick e Worthen), mortalidade entre adultos pré-aposentadoria (Hummer et al.), causas específicas de morte (Rogers et al.), saúde entre negros (Ellison et al.) e judeus (Eberstein e Heyman), comportamento sexual de risco e saúde reprodutiva entre mórmons (Heaton) e saúde e acesso a serviços de saúde entre novos imigrantes (Ebaugh).

A terceira e última parte do livro, de olho no futuro, está dividida em dois capítulos. O primeiro (Sherkat) analisa a demografia da religião nos Estados Unidos, no período de 1972 a 2002, com ênfase na distribuição da população entre as diferentes denominações e na dinâmica da afiliação. Já o segundo capítulo (Ellison e Hummer) encerra o volume com uma lista de quatro temas que são fundamen-

\footnotetext{
* Professora associada, Departamento de Demografia e Cedeplar/Universidade Federal de Minas Gerais - UFMG.
} 
tais para garantir o avanço dos estudos científicos sobre religião durante o século XXI: aprimorar conceitos e medidas de religião em pesquisas de base populacional; entender melhor os subgrupos populacionais, especialmente no que tange à sua composição racial/étnica; esclarecer se as relações entre religião e as variáveis demográficas são causais, bidirecionais ou espúrias; e, mais importante, continuar na luta por dados de base populacional de qualidade, uma vez que o censo demográfico americano não pergunta sobre religião há várias décadas.

Apesar de cobrir muitos aspectos da relação entre religião, famílias e saúde, o livro tem duas lacunas temáticas importantes do ponto de vista da demografia. No que se refere às famílias, a abordagem da nupcialidade está longe de esgotar o tema. Há um capítulo sobre casamentos e recasamentos, mas estão ausentes estudos sobre descasamentos (divórcios e separações) e uniões consensuais. Com relação à saúde, o foco na população adulta e idosa deixou de fora crianças e adolescentes. Seria interessante ter um capítulo sobre mortalidade infantil e na infância, mesmo sabendo que estes são eventos raros e, portanto, difíceis de serem mensurados a partir de dados não censitários.

Os demógrafos brasileiros têm muito a aprender com este livro. A despeito de fazer parte das formulações teóricas sobre a transição demográfica clássica e, sobretudo, a segunda transição demográfica, a religião tem sido sistematicamente negligenciada na demografia brasileira. Ao trazerem o tema à baila, os artigos lembram aos demógrafos que, mais do que uma variável, a religião é uma peça importante no grande quebra-cabeça da vida social e, portanto, não se pode negligenciá-la. Finalmente, talvez a maior contribuição deste volume seja mostrar que os estudos cuja variável independente de interesse é a religião não são necessariamente conservadores ou dogmáticos e podem ter importantes implicações para as políticas públicas.

Ora tachados de funcionalistas, ora acusados de conservadores, os primeiros encontros entre a demografia e a religião nos Estados Unidos, ainda na década de 1960, nem sempre foram bem-sucedidos. Segundo Ellison e Hummer, a partir do final dos anos 1980, o interesse ressurgiu, uma vez que a religião enquanto instituição permaneceu forte e os americanos continuaram religiosos, ao mesmo tempo em que houve um crescimento da espiritualidade fora das instituições, a diversidade religiosa da população aumentou, atores religiosos reapareceram no cenário político e pesquisas sobre saúde com base populacional passaram a incluir perguntas sobre religião e religiosidade.

Este livro é, sem dúvida, o encontro definitivo entre a demografia e a religião nos Estados Unidos no que tange à sua relação com as famílias e a saúde. O Brasil, palco de grandes mudanças no cenário religioso nas últimas quatro décadas e detentor de dados censitários sobre filiação religiosa de sua população há pelo menos 70 anos, é de certa forma iniciante, pois os estudos sobre a relação entre demografia e religião estão apenas começando. No entanto, diante da importância da religião na vida de uma grande parcela da população brasileira, do crescente interesse pelo tema por parte dos demógrafos, da existência de dados e das inúmeras possibilidades de estudos nesta área, já existe um encontro marcado. Que não seja preciso esperar 15 anos!

Recebido para publicação em 18/10/2011 Aceito para publicação em 04/11/2011 